\title{
CARTOGRAFIA DOS IMPACTOS AMBIENTAIS NO PARQUE NACIONAL DA CHAPADA DOS VEADEIROS (GO)
}

\author{
environmental impacts cartography at Chapada dos Veadeiros National Park, State of Goiás
}

\author{
Carlos Shiley Domiciano* \\ Ivanilton José de Oliveira**
}

\begin{abstract}
Resumo
Este trabalho tem como objetivo principal demonstrar, por meio de estudos cartográficos, os impactos ambientais decorrentes da ação do turismo no Parque Nacional da Chapada dos Veadeiros (PNCV) e no Distrito de São Jorge, município de Alto Paraíso-GO e nas suas imediações, bem como averiguar a percepção desses impactos junto aos turistas, funcionários do Parque e representantes da comunidade local. Para sua realização seguiu-se a proposta metodológica de André Journaux, de cartas de síntese para a elaboração de um Mapa de Unidade de Paisagens, onde foram registrados os impactos ambientais. Também foram feitas observaçoes desses impactos e entrevistas com turistas, moradores e administradores locais e do PNCV. Constatou-se que estes impactos marcam a paisagem da região, refletindo as práticas sociais ocorridas na localidade.
\end{abstract}

Palavras-chave: Impactos ambientais, Cartografia, Turismo, Chapada dos Veadeiros.

\begin{abstract}
The main objective of this study is to show, through cartographic studies, the environmental impacts of the tourism at Chapada dos Veadeiros National Park in São Jorge District, Alto Paraíso City-Goiás and outskirts Also to verify the tourists perception, the public functionaries perception and local community perception of this impacts. The André Journaux methology of synthesis maps was used for to elaborate one Landscape Unity Map, where the environmental impacts was registered. The autors observed the impacts and interviewed tourists, residents, local administrators and national park administrators. Was evidenced that impacts mark the local landscape, reflecting the social practices of the place.
\end{abstract}

Key words: Environmental impacts, Cartography, Tourism, Chapada dos Veadeiros.

\begin{abstract}
Résumé
Ce travail vise à démontrer, au moyen d'études cartographiques, les impacts environnementaux résultant de l'action du tourisme dans le Parc National de Chapada dos Veadeiros (PNCV) et le district de São George, Alto Paraiso-GO et de ses environs, ainsi que de déterminer la perception de ces effets entre les touristes, les responsables du Parc et des représentants des communautés locales. Pour sa réalisation, suivi par la méthodologie proposée par André Journaux, de cartes de synthèse, pour la préparation d'une Carte des Unités de Paysage, dans lequel les impacts environnementaux ont été enregistrées. Ont également été faites les observations de ces impacts et les entrevues avec les touristes, les résidents et les administrateurs locaux et du PNCV. Il a été constaté que les impacts marquent le paysage de la région, ce qui reflète les pratiques sociales qui ont eu lieu dans la localité.
\end{abstract}

Mots-clés: Impacts environnementaux, Cartographie, Tourisme, Chapada dos Veadeiros.

(*) Doutorando em Ciências Ambientais na Universidade Federal de Goiás, Prof. do Curso Superior de Tecnologia em Gestão de Turismo do Instituto Federal de Educação, Ciência e Tecnologia de Goiás - R. 75, n 46, Centro, Goiânia-GO, Brasil, Tel: (+5562) 32272700 - carlosdomiciano@yahoo.com.br

(**) Prof. Dr. do Instituto de Estudos Socioambientais da Universidade Federal de Goiás - Campus Samambaia, Caixa Postal 131, CEP: 74.001-970, Goiânia (GO), Brasil, Tel:: (+55 62)35211184 - ivanilton.oliveira@gmail.com 


\section{INTRODUÇÃO}

O turismo, muito além de ser uma atividade econômica, apresenta-se como um processo de produção social que interfere em vários setores da sociedade, como o setor econômico, o social, o cultural e o ambiental. Tendo se desenvolvido concomitantemente à Revolução Industrial, a atividade, que também é denominada de "indústria do turismo" por muitos autores, para se estabelecer utiliza-se de recursos do meio onde se encontra. À primeira vista, os benefícios econômicos da atividade sobressaem, gerando uma suposta ideia de progresso e desenvolvimento nos locais onde está assentada, mas com o passar do tempo, surgem as evidências dos impactos negativos nas comunidades em que o turismo proliferou, em virtude da exploração desmedida de seus recursos.

Nas últimas décadas do século passado, o aumento da crise ambiental no mundo e o estabelecimento de uma "consciência ecológica", fizeram com que se buscasse um tipo de turismo alternativo, mais em contato com a natureza, à procura do resgate de uma maior qualidade de vida, resultante da transformação de valores e mudança de hábitos de vida da sociedade. Dessa maneira, aparece a forma de turismo de natureza ou ecológico, ou ainda o ecoturismo, como uma alternativa ao padrão do turismo convencional, em que o contato com a natureza "intocada" é o seu mote principal.

Mesmo com esse tipo de turismo ecológico, ainda que em suas formas controladas, como é o caso de visitas nas Unidades de Conservação (UC), os impactos ao ambiente tornam-se inevitáveis, pois podem se transformar num fator de degradação ambiental e dar origem a desequilíbrios em ambientes naturais protegidos.

A partir dessa ideia, realizou-se um estudo para averiguar a ocorrência de impactos ambientais provocados pela atividade turística em uma UC e seu entorno, neste caso o Parque Nacional da Chapada dos Veadeiros (PNCV) e suas adjacências, mais especificamente o Distrito de São Jorge, onde se localiza o portão de entrada do referido parque, pertencente ao município de Alto Paraíso de Goiás-GO, distante em média a $460 \mathrm{~km}$ de Goiânia. É uma região que se destaca entre os exemplos de rico patrimônio natural do estado de Goiás e do país, pois se apresenta como uma das mais preservadas áreas do cerrado brasileiro, além de representar a maior área de vegetação nativa específica de cerrado de altitude do território goiano, que se restringe a apenas 3\% do cerrado como um todo, dos quais aproximadamente $98 \%$ encontram-se na Chapada dos Veadeiros (OLIVEIRA, 2007).

\section{CARACTERIZANDO A ÁREA DE PESQUISA}

O PNCV, fundado em 1961, conta, atualmente, com uma área de 65.514 ha, que abrange parte dos municípios de Alto Paraíso de Goiás, Cavalcante, Colinas do Sul e Teresina de Goiás (Figura 1) - destacando-se o primeiro, com o distrito de São Jorge -, que desenvolveram um importante fluxo turístico a partir dos anos de 1980, com ênfase no ecoturismo, turismo de aventura e turismo cultural. Segundo informações da administração do Parque, o PNCV recebeu nos últimos cinco anos, em média, cerca de vinte mil visitantes, sendo que no ano de 2011, só até julho já havia recebido mais de treze mil pessoas (Tabela 1).

A área de visitação do Parque é composta por duas trilhas, que levam aos seus atrativos principais, sendo que a primeira, com aproximadamente $10 \mathrm{~km}$, conduz aos Canyons e à Cachoeira das Cariocas. A segunda, com um percurso médio de $11,5 \mathrm{~km}$, passa pelos saltos I (120 m de altura) e II ( $80 \mathrm{~m}$ de altura) e as corredeiras do Rio Preto. A capacidade de lotação das trilhas, definida pela administração do Parque, é de 200 pessoas/dia para a trilha 1 e 250 pessoas/dia para a trilha 2 .

Fora da área do Parque Nacional, nos arredores do Distrito de São Jorge, existem cerca de 20 atrativos, entre cachoeiras e corredeiras, que variam de 3 a $150 \mathrm{~m}$ de altura, em propriedades 
particulares, dentre as quais se destacam as cachoeiras do Vale da Lua e a do Raizama. Todos esses turistas, invariavelmente, passam pelo Distrito de São Jorge que, de acordo com a administração local, possui 28 pousadas, 15 áreas de camping e residências que alugam parte de suas dependências para alojamento das pessoas.

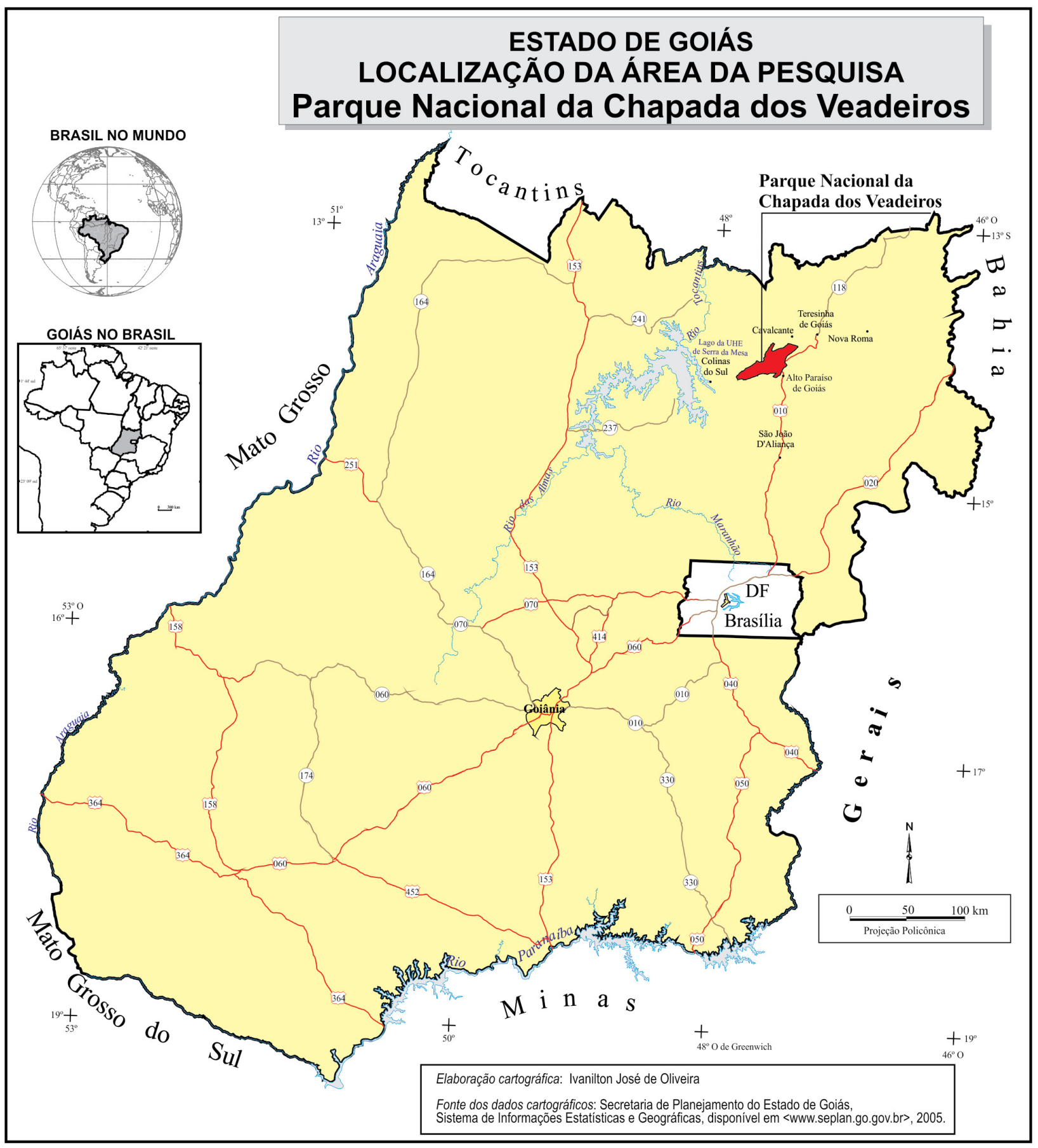

Figura 1 - Mapa de localização do PNCV.

Pelo exposto apresentado e considerando que, conforme a administração local, não existe qualquer estudo de capacidade de suporte dos locais visitados (a não ser os limites de lotação das trilhas do PNCV), realizou-se esta investigação e o registro cartográfico dos impactos ambientais provocados pela atividade turística nas áreas de visitação do Parque Nacional, no distrito de São 
Jorge e em suas adjacências. Buscou-se, ainda, compreender a percepção desses impactos ambientais junto aos turistas, funcionários do PNCV e comunidade local, no intento de compreender a participação das pessoas nesse processo histórico de transformação, que é natural e também social (MARTINELLI e PEDROTTI, 2001).

Tabela 1 - Número de visitantes do PNCV - 2006-2011

\begin{tabular}{c|c|c|c|c|c|c}
\hline ANO & 2006 & 2007 & 2008 & 2009 & 2010 & $2011(\mathrm{jul})$ \\
\hline VISITANTES & 17.441 & 20.173 & 17.407 & 23.104 & 20.617 & 13.756 \\
\hline
\end{tabular}

Fonte: Administração do PNCV (2011). Organização dos autores.

\section{TURISMO E IMPACTOS AMBIENTAIS}

De um modo geral, o turismo é uma atividade impactante em todas as suas modalidades, pois depende de uma série de intervenções no espaço físico para se desenvolver, como a construção de obras de infraestrutura, a exemplo das rodovias, dos aeroportos, das instalações turísticas (hotéis, restaurantes, áreas de lazer etc.), que são necessárias para o acontecer do trade turístico. Como frisou Dias (2003, p. 87), "ocorre que os impactos negativos desse desenvolvimento podem gradualmente destruir os recursos ambientais dos quais depende o turismo", além de permear outros âmbitos, como o social, o cultural, o econômico etc.

A Resolução 001/86 do Conselho Nacional do Meio Ambiente (CONAMA), do Ministério do Meio Ambiente (MMA), no Artigo $1^{\circ}$, define como impacto ambiental

qualquer alteração das propriedades físicas, químicas, e biológicas do meio ambiente, causada por qualquer forma de matéria ou energia resultante das atividades humanas que, direta ou indiretamente, afetam: a saúde, a segurança e o bem estar da população; as atividades sociais e econômicas; a biota; as condições estéticas e sanitárias do meio ambiente e a qualidade dos recursos ambientais.

Segundo Dias (2003), a atividade turística foi considerada, por muito tempo, uma "atividade econômica limpa, não poluente" que levava oportunidades a várias localidades, embora essa visão tenha sido mudada nos dias atuais, com o apontamento de diversos estudos de impactos ambientais oriundos do turismo, nos locais onde a prática ocorre, e em seus respectivos ecossistemas. Apesar desses problemas, o autor sugere que o turismo ainda pode contribuir potencial e efetivamente para o gerenciamento do meio ambiente, corroborando com o que afirma Rocktaeschel (2006, p. 22), de que "a conservação deste último é imprescindível para o êxito da atividade turística".

Dentre as tipologias do turismo, as modalidades que mais se utilizam do meio natural para as suas práticas são o turismo ecológico e o ecoturismo. Para Beni (2002, p.33), o primeiro, também chamado de turismo de natureza ou verde, se dá pelo "deslocamento de pessoas para espaços naturais, com ou sem equipamentos receptivos, motivados pelo desejo/necessidade de fruição da natureza, observação passiva da flora, da fauna, da paisagem e dos aspectos cênicos do entorno". A segunda modalidade, o ecoturismo, é aquela dada em espaços naturais delimitados e/ou protegidos pelo Estado ou controlados por alguma organização, como associações locais ou organizações não-governamentais (ONG), com planejamento do uso sustentável de seus recursos naturais e culturais, em que as atividades, a exemplo do turismo ecológico, podem ser realizadas, desde que rigorosamente observadas as restrições de uso desses espaços (BENI, 2002). Esse tipo de turismo ocorre, geralmente, nas UC, dentre as quais se destacam os parques nacionais (PARNA), como é o caso em estudo. 
Percebe-se, dessa forma, que tais modalidades turísticas utilizam o ambiente como substrato para consubstanciar a produção de seus serviços, pois a natureza, os bens naturais tornam-se atrativos para a recepção das pessoas, ou para induzi-las a se deslocar até onde se encontram esses recursos, que se constituem em "matéria-prima" (LEMOS, 2005), que devem ser transformados em "produtos turísticos" (BENI, 2002).

Conforme vai modificando os espaços, para produzir os lugares turísticos, o homem vai antropizando a natureza, alterando seus ciclos naturais e ameaçando a sua relação de 'ecodependência' (FONTELES, 2004), que passa, então, a gerar os problemas ambientais, que vão impactar as localidades onde a atividade turística se desenvolve. Conforme Rozo (2002),

los desarollos turísticos han generado impactos ambientales y sócioculturales negativos em áreas de alta riqueza paisajística y en donde convivían comunidades étnicas de manera equilibrada con su entorno. De otra parte, el impacto sobre los ecosistemas em algunos casos há acabado con su própria razón de ser, con la motivación principal de los desplazamientos de los viajeros: el paisaje (ROZO, 2002, p.126).

Em se tratando do turismo ecológico, e mais especificamente do ecoturismo, pelo fato de ser o ambiente natural o atrativo maior, os impactos ambientais são mais ressaltados. Soares (2007, p. 3), analisando a questão dos impactos ambientais em unidades de conservação brasileiras, aponta que "apesar de as unidades de conservação serem locais destinados à conservação ambiental, exercício da educação ambiental, pesquisa científica e contemplação da natureza em seu estado original ou mais próximo deste, a prática da atividade turística muitas vezes não atende esses princípios". O autor lista uma série de impactos mais presentes nas UC, relacionados com a atividade turística:

- mudanças no comportamento dos animais ocasionados pelo número excessivo de visitantes em uma determinada área;

- erosão, distúrbios no comportamento dos animais, perda de habitat da fauna e comprometimento da qualidade visual da paisagem em função da construção de infraestrutura, de áreas para descanso e da abertura de trilhas e acessos;

- alterações no comportamento dos animais e empobrecimento de sua dieta, ocasionados pelo hábito dos visitantes de alimentar os animais;

- interferência no ambiente sonoro, visual e olfativo típico da área, resultantes do barulho, excesso de cores e odores estranhos dos visitantes;

poluição do solo, dos cursos d'água e interferência na alimentação dos animais, ocasionados pela deposição inadequada do lixo;

- destruição da vegetação, morte de animais e empobrecimento do solo, ocasionados pelos incêndios; - remoção de atrativos naturais (pedras, vegetais, pequenos animais) para servirem de souvenirs para os visitantes (SOARES, 2007, p.3).

Para a Chapada dos Veadeiros, a região do objeto em foco, mencionam-se dois estudos realizados sobre os impactos do turismo. No primeiro, Silva e Nunes (2005) analisam os efeitos socioeconômicos da pavimentação da estrada GO-239, que liga Alto Paraíso de Goiás à Vila de São Jorge, em que frisam os seus impactos negativos, relacionados ao uso e ocupação do solo, influenciados pela implantação de novos serviços e empreendimentos no espaço do Distrito. No segundo, Mendonça Filho (2007) elenca uma sequência de problemas advindos da "prática ecoturística", entre eles: deposição irregular de resíduos sólidos em "lixões"; deposição irregular de esgoto doméstico, por fossas rudimentares ("fossas negras"); desmatamento irracional e/ou ilegal de cerrado; pichação de monumentos naturais; incremento dos processos erosivos nas cidades e nas 
trilhas; coleta irracional de plantas ornamentais e medicinais; caça ilegal; introdução de espécies exóticas de plantas e animais nos ecossistemas naturais; dentre outros.

Assim, os impactos decorrentes da atividade turística ficam de certa forma marcados no espaço das comunidades onde o turismo se desenvolve, ainda mais em se tratando de uma modalidade que tem por mote principal o ambiente, como é o caso do ecoturismo e do turismo ecológico, que se desencadeiam no PNCV e nas suas imediações. Para a demonstração desses impactos, realizou-se este estudo, visando a localização e classificação, pelo registro in loco e posterior mapeamento, associados à percepção do problema por parte das pessoas que estão em contato com essa realidade.

\section{O MAPA DOS IMPACTOS: CARTOGRAFIA AMBIENTAL}

Um dos elementos básicos para a consecução da atividade turística é o espaço geográfico, a base física em que acontece o contato entre a oferta e a demanda do setor e onde se encontram as comunidades locais, que são as primeiras a sofrerem as consequências dos impactos causados pelo desenvolvimento do turismo (DIAS, 2003). Assim, intenta-se demonstrar com esse trabalho o mapeamento dos impactos ambientais causados pela atividade turística no PNCV e seu entorno, estabelecendo relações entre estes e a respectiva atividade, reconhecida como um fenômeno social, pois conforme destacou Zacharias et al. (2009, p. 3), "a análise integrada do ambiente pode fornecer importantes contribuições ao estudo das práticas sociais, sobretudo do seu relacionamento com a dinâmica física do ambiente em que a sociedade se insere".

Partindo desse princípio, a cartografia ambiental propõe não apenas mostrar um determinado espaço geográfico, mas também que se deve reportar à sua "materialidade", tentando demonstrar as relações acontecidas naquele meio, que levaram à produção daquele cenário.

Qualquer paisagem, por mais simples que seja, é sempre social e natural, subjetiva e objetiva, espacial e temporal, produção material e cultural, real e simbólica. Para sua completa apreensão, não basta a análise separada de seus elementos. É preciso compreender sua complexidade, que é dada pela forma, estrutura e funcionalidade (MARTINELLI e PEDROTTI, 2001, p.41).

Para Archela e Rosolém (2009), a cartografia permite a exposição de forma expressiva e representativa da ação humana sobre a natureza, mostrando a apropriação e transformação dos espaços pelo homem, sem deixar de levar em consideração os seus condicionantes naturais, pelo fato que contribui para o entendimento de questões ambientais. Dessa forma, a utilização de mapas que indicam os problemas ambientais de uma localidade pode ser um elemento importante no seu processo de gestão, pois contribui para o processo de tomada de decisões e na representação espacial desses problemas (ZACHARIAS et al., 2009). Oliveira (2005) complementa que a cartografia deve ser uma forma de comunicação, um processo de construção de "caricaturas" da realidade, nas quais se encontram representadas as características marcantes do espaço real.

$\mathrm{Na}$ análise dos problemas ambientais, a cartografia torna-se um valioso instrumento no estudo das unidades de paisagem (ZACHARIAS et al., 2009). A paisagem, por sua vez, ressalta Rozo (2002), é o principal motivo para as viagens turísticas. Então, observa-se que, tanto a cartografia quanto o turismo se utilizam de um mesmo "objeto" para atingir os seus objetivos. Para este, a paisagem torna-se um produto a ser consumido; para a cartografia, porém, é um complexo que envolve uma "conjunção de fatores distintos, como a história geológica, a morfogênese do relevo, o clima em seu movimento, a dinâmica biológica e a participação da ação humana em sua evolução histórica" (MARTINELLI e PEDROTTI, 2001, p.41).

A cartografia, quando se dedica ao estudo das unidades de paisagem, como descrita anteriormente configura-se na cartografia ambiental, que procura representar a relação dos componentes 
da natureza como um sistema e dela com o homem. Para tanto, divide-se em cartografia analítica e cartografia de síntese. Alonso (2002) se refere a essas duas propostas como "Cartografia Ambiental Setorial" e "Cartografia Ambiental Integrada".

A primeira trata de mapeamentos temáticos, na construção de cenários que retratam um conteúdo concreto (ZACHARIAS et al., 2009). Segundo Rech, Oliveira e Loch (2007), um mapa temático pode evidenciar mais do que uma posição do lugar, pois pode caracterizá-lo, representando as suas características, dadas em um ou mais temas, como mapa geoambiental, geomorfológico etc. Por sua vez, a cartografia de síntese (mapa-síntese), concentra-se na integração das informações, ordenadas por atributos específicos, que constituem escalas taxonômicas de paisagens (ZACHARIAS et. al., 2009). Conforme Archela e Rosolém (2009, p.2), há uma dificuldade em se adotar uma metodologia específica para a cartografia ambiental, embora reconheçam que "são os mapas de síntese os que mais se identificam com a proposta da cartografia ambiental, ao representar a dinâmica do meio ambiente", seguindo o pressuposto metodológico do geógrafo André Journaux.

A cartografia ambiental pode ser um elo entre o meio e a sociedade, na medida em que reflete as ações humanas numa determinada época e localidade. Destarte o escopo deste trabalho, de esquadrinhar os principais impactos ambientais decorrentes da atividade turística no PNCV e seu entorno, utilizando-se a proposta metodológica de cartografia ambiental de Journaux.

\section{METODOLOGIA}

A construção do mapa ambiental seguiu a proposta de Jornaux (1985), cujas cartas de síntese são tidas como cartas de sensibilização aos problemas ambientais, aplicáveis ao planejamento.

Partindo da base cartográfica elaborada por Oliveira (2007), de um "Mapa de Unidades de Paisagens" (Figura 2), foram feitos os registros dos impactos ambientais relacionados direta ou indiretamente à atividade turística na área do PNCV e seu entorno.

No trabalho de campo para coleta de dados e informações sobre os impactos, percorreram-se os locais e caminhos de uso mais intensivo na prática do turismo, nas trilhas do PNCV, além da sede urbana diretamente ligada à área da pesquisa, ou seja, o Distrito de São Jorge e suas imediações, em função de concentrarem o maior fluxo de visitantes.

Os impactos percebíveis, a exemplo de "degradação" de trilhas, focos ou indícios de queimadas, erosões, lançamento de lixo, presença de espécies invasoras etc. foram registrados com a coleta de pontos de GPS e fotografias, além da descrição textual, para posterior transcrição nos formatos tabular e cartográfico.

Os impactos conhecidos, mas não passíveis de apontamento in loco, foram registrados por meio das informações obtidas junto às instituições competentes, como o Instituto Chico Mendes de Conservação da Biodiversidade (ICMBio) e a administração local do Distrito de São Jorge, e também por meio de entrevistas com moradores locais, proprietários de empreendimentos particulares e condutores de visitantes.

A metodologia de Journaux (1985) foi adaptada para a realidade do PNCV e seu entorno. Com esses registros, verificou-se a correlação entre a intensificação do uso do espaço pelas atividades turísticas e a ocorrência de impactos ambientais. Ao mesmo tempo, a carta de unidades de paisagens já faz indicações de certos níveis de fragilidade dos terrenos, na medida em que demonstra a integração entre as características geológicas, geomorfológicas, pedológicas e de cobertura vegetal. Portanto, a superposição dos registros de impactos a essa carta permitiu vislumbrar os pontos de maior ou menor significância em termos dos impactos, algo fundamental para a definição de diretrizes para o planejamento ambiental. 
DOMICIANO, C. S.; OLIVEIRA, I. J.
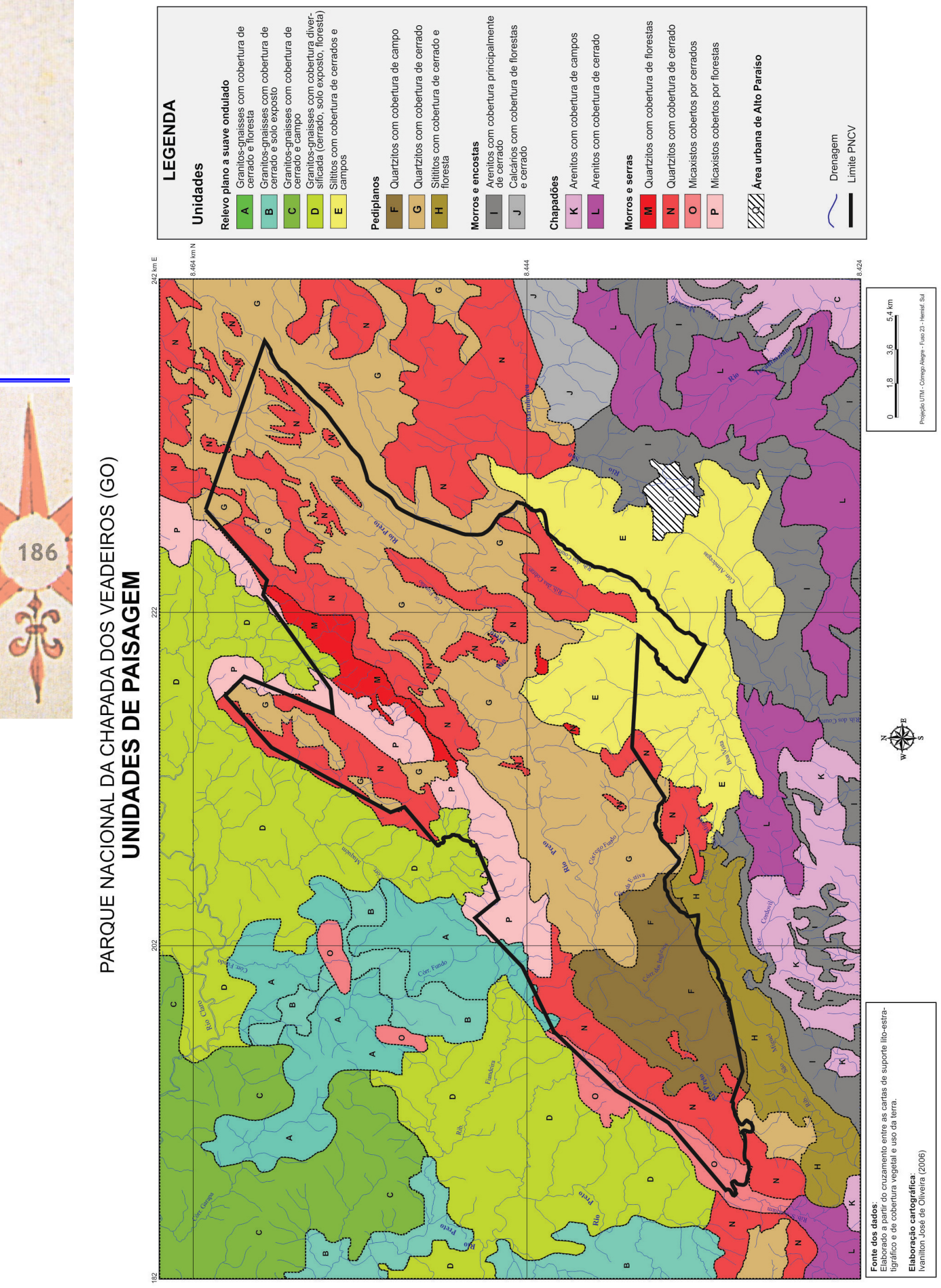

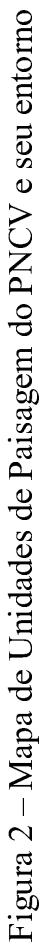




\section{OS IMPACTOS AMBIENTAIS NO PNCV, NO DISTRITO DE SÃO JORGE E ARREDORES}

Ao se analisar os impactos ambientais decorrentes da atividade turística no PNCV e no Distrito de São Jorge, faz-se necessário reportar ao contexto histórico da região, detendo-se na gênese das principais atividades que aí se desenvolveram. Inicialmente, a garimpagem marcou o seu povoamento, induzida por uma demanda de cristal de rocha (quartzo) aí existente, material muito utilizado na indústria de equipamentos eletrônicos de comunicação e de guerra, que determinou o ajuntamento de pessoas oriundas dos estados da Bahia e de Minas Gerais à busca dos cristais, culminando com a fundação da Vila de São Jorge, no começo do século XX.

Tal atividade manteve-se até por meados dos anos de 1950, quando então entrou em declínio, obrigando os garimpeiros a se sustentar pela agricultura de subsistência e pelo extrativismo (plantas do cerrado e cristais). Em 1961, com a criação do Parque Nacional do Tocantins (que em 1972 passaria a denominar-se Parque Nacional da Chapada dos Veadeiros) uma nova configuração na vida das pessoas da Vila se apresentou, pois "o acesso de técnicas e práticas básicas de sobrevivência desta população foram limitadas pelas exigências de proteção da Unidade de Conservação" (SILVA, 2003, p. 55). Esse fato apontou para um novo rumo em termos de atividade econômica para a região, o ecoturismo, que se instalou de forma incipiente a partir dos anos de 1980 e atingiu a conformação atual no final dos anos 1990 (SILVA, 2003; OLIVEIRA, 2007; BRANDÃO e BARRETO, 2009).

Tais práticas pretéritas e as que ocorrem atualmente na localidade deixam as suas marcas na paisagem, colocando à mostra o que foi o retrato de uma época, neste caso, duas épocas: a primeira, identificada pela garimpagem do cristal e, a segunda, pelo ecoturismo. Em ambos os momentos, é importante que se ressalte a participação das pessoas (garimpeiros, moradores, turistas, administradores do Parque e do Distrito etc.) no recorte desse espaço.

A forma como os homens se relacionam com a natureza depende do modo como se relacionam entre si, o que é determinado pelas relações sociais vigentes em certo modo de produção, em dado momento do percurso da história da sociedade humana (MARTINELLI e PEDROTTI, 2001, p.39).

Assim, as marcas, ou seja, os registros deixados no ambiente, refletem as ações e relações aí estabelecidas, gerando os impactos socioambientais, ou somente impactos ambientais de uma comunidade, questão mais específica a ser retratada a seguir. Os impactos enfocados aqui são, na sua grande maioria, decorrentes da atividade turística que se desenvolve na região, vinculados diretamente ou indiretamente ao setor. Todavia, ainda se registram alguns impactos advindos da garimpagem, principalmente nas trilhas do PNCV, e da atividade agropecuária, no seu entorno. Os impactos apresentados podem ser tipificados em dois grupos, a saber: os percebidos e os conhecidos. Os primeiros estão relacionados à capacidade de percepção das pessoas que habitam, trabalham e visitam a localidade - estão, portanto, em destaque na paisagem; os segundos estão em consonância com os registros feitos na base de relatos de observação dos pesquisadores, dos agentes de fiscalização (ICMBio), das autoridades locais, entre outros - são dessa forma, menos evidentes, mas igualmente impactantes.

\section{OS IMPACTOS PERCEBIDOS}

Os impactos são mais expressivos ao longo da via de acesso à localidade, no caso a estrada GO-239 (Figura 3), que faz a interligação dos municípios de Alto Paraíso de Goiás e Colinas do Sul, cujo movimento aumenta nos períodos de alta temporada turística na região e também por ser passagem a quem se dirige (via Colinas do Sul) a um outro ponto turístico importante do estado de Goiás, o Lago da Serra da Mesa. 
No trecho inicial, o caminho é pavimentado (cerca de $22 \mathrm{~km}$ ), sendo que nos $14 \mathrm{~km}$ antes de se chegar à sede do distrito não existe pavimentação asfáltica e, devido ao trânsito excessivo de veículos que aí trafegam, em direção a São Jorge e aos atrativos do seu entorno, observou-se, em vários pontos, o "esfacelamento" do leito da estrada, dificultando a passagem dos transeuntes, moradores ou visitantes (Figura 4A). Em decorrência desse fato forma-se uma grossa camada de poeira, que com o trânsito de veículos, se dispersa pelo ar, tirando a visibilidade do caminho e depositando-se nas plantas, às margens da estrada, obscurecendo-lhes a coloração natural (Figura 4B). Em alguns desses pontos da estrada já foi necessário inclusive construir desvios para facilitar o seguimento da viagem. E em determinados locais foram detectados focos de erosão ou desbarrancamento na beira da estrada, indicando certa fragilidade da estrutura do terreno, como aponta o Plano Diretor Ambiental/Urbano de Alto Paraíso (1998), segundo o qual os solos de grande parte do município apresentam suscetibilidade à erosão.

Outro impacto observado em alguns trechos da estrada GO-239, especialmente aqueles próximos aos atrativos turísticos e à sede do distrito, são as placas de anúncios dessas localidades e da sinalização turística destacando-se na visualização da paisagem, a maioria delas com o agravante de apresentarem-se pichadas, o que desvirtua a sua função original.

Ainda, na estrada GO-239, próximo a sede do Distrito, foram detectados vários pontos com deposição de lixo, entulhos de construção e cisco, proveniente da limpeza de quintais, acumulando-se ao longo do trecho da via, confrontante com o perímetro urbano. Os impactos concentram-se nos locais onde há maior aglomeração de turistas, como no núcleo urbano do Distrito e nos atrativos das propriedades particulares do Vale da Lua e do Raizama (Figura 5). A pressão antrópica aumenta sobre os recursos naturais da localidade, principalmente nas épocas coincidentes com a alta temporada (julho) e feriados prolongados, quando o número de visitantes pode chegar ao quádruplo da população residente, que é de cerca de 800 habitantes, segundo o agente da Administração Municipal Local (entrevista em set./2011).

Na sede do Distrito de São Jorge podem ser observados os impactos relacionados ao aparelhamento urbano da localidade, em função de ser o ponto de referência para a recepção dos turistas que se destinam ao PNCV e aos atrativos do seu entorno. São as "intervenções no espaço físico" (DIAS, 2003) que a atividade turística necessita para se desenvolver.

Ainda decorrente do excesso de veículos que circulam pelas ruas do distrito, faz-se necessária a manutenção da sua trafegabilidade, o que exige o "patrolamento" das suas vias de circulação, ocasionando um novo impacto de escavação das beiras das ruas, que não têm calçamento, o que provoca erosão nas ruas mais declivosas e carregamento de areia para as partes mais baixas do núcleo urbano, redundando em alagamentos nessas partes, na época das "águas", conforme relatos verbais da Administradora Municipal Local .

Outro impacto indiretamente ligado ao turismo refere-se à expansão da estrutura urbana local, que para ocorrer busca áreas para o estabelecimento de novas residências, como é o caso do loteamento denominado de São Jorge II, com 26 imóveis, que prolongou o perímetro urbano do Distrito, rumo à área de preservação contígua ao Parque Nacional.

A exemplo do que ocorre na GO-239, nas imediações da sede do Distrito, onde se depositam lixo e entulho (Figura 6A), nas suas ruas limítrofes também se observou essa prática, com o agravante de que o material é assentado nas saídas de água das enxurradas (Figura 6B), contribuindo para o entupimento e posterior alagamento, conforme citado anteriormente. 


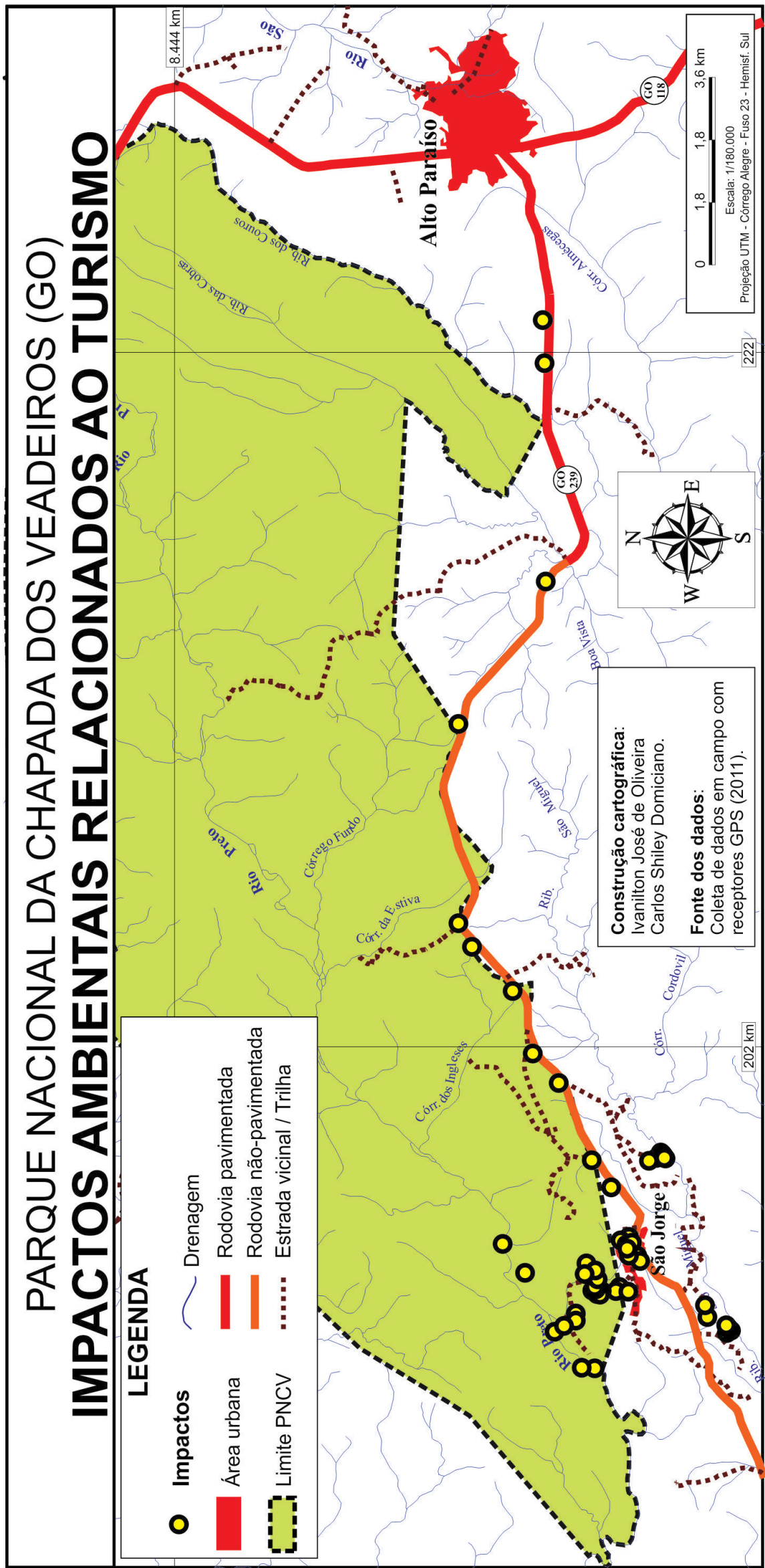




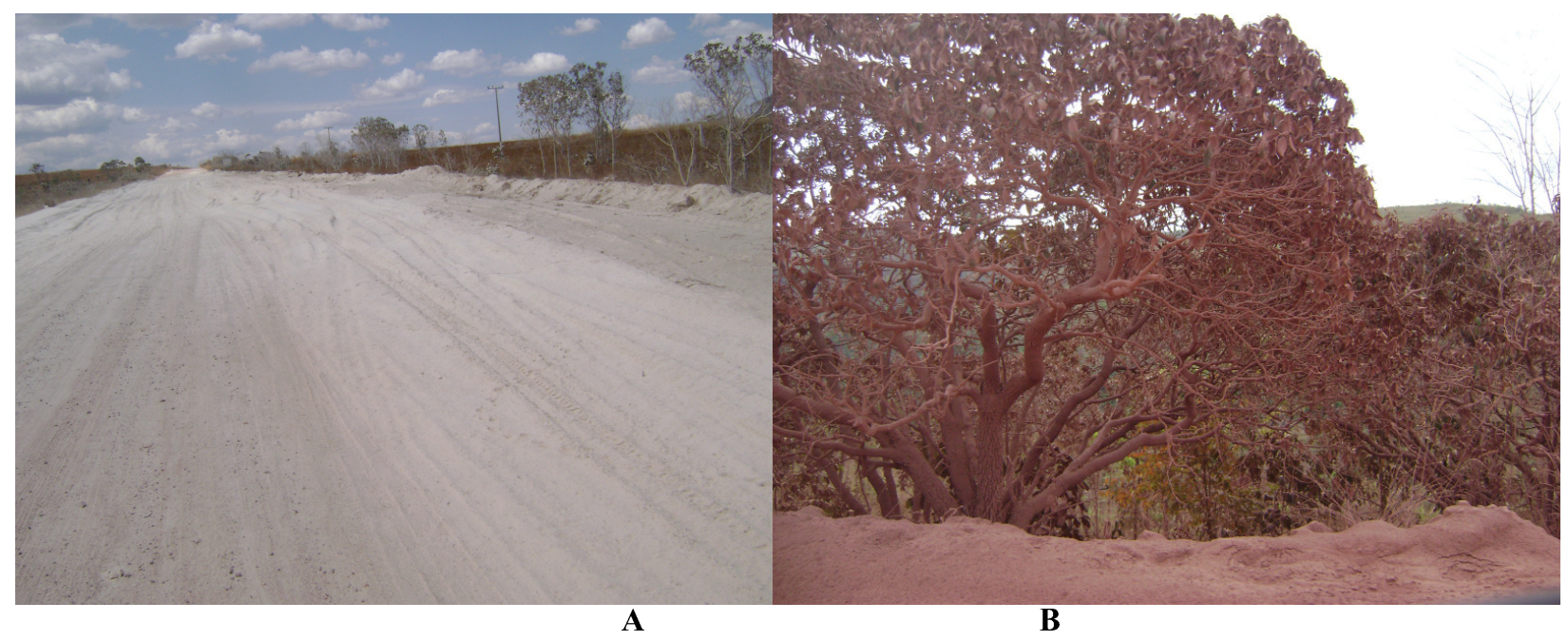

Figura 4 - Fotos demonstrando o esfacelamento e poeira na margem da estrada GO-239 (set./2011). Fonte: Os autores.

Outro elemento impactante no distrito é a ocorrência em demasia de placas e anúncios, principalmente nos cruzamentos da rua principal, causando uma forte poluição visual na "vila", retirando-lhe certo ar bucólico, que a caracterizava até alguns anos atrás. Nos arredores do Distrito, observou-se, em vários locais, a presença de plantas invasoras, principalmente de pastagens do tipo braquiária (Brachiaria sp.), competindo e tomando lugar da vegetação nativa.

A visualização do mapa (Figura 5) mostra também que os impactos são mais incidentes nos locais em que não há um maior controle da visitação dos turistas, nos atrativos das propriedades particulares, entre eles as cachoeiras e corredeiras do Raizama e do Vale da Lua, ambos aproveitando o curso do rio São Miguel, onde não se exige a obrigatoriedade do acompanhamento de um guia de turismo, embora exista a cobrança de taxas de ingresso. Em entrevista, o administrador de um desses empreendimentos (set/2011) afirmou que em ocasiões de grande movimento no local é necessário fazer a coleta de lixo com frequência, em virtude da grande quantidade de dejetos que os turistas deixam ao longo das trilhas e nas cachoeiras.

No Raizama, os impactos mais visíveis são as obras civis da sede do empreendimento, como bar, palco e estacionamento. Nas trilhas $(2.300 \mathrm{~m})$ são notadas as marcas nos troncos das árvores de um incêndio que atingiu o local em 2010, e as intervenções realizadas pelo proprietário, tais como pontes, passarelas e escadas de madeira para facilitar o acesso aos atrativos. No Vale da Lua, são registrados como elementos impactantes: as obras civis da sede e o estacionamento; lixo depositado em alguns trechos ao longo da trilha $(600 \mathrm{~m})$; degradação da trilha em alguns pontos mais íngremes (Figura 7A), apresentando marcas de erosão, com certo trecho em desuso, em função de ter-se construído outro substituto. O que mais se destacou em termos de impacto, no entanto, foi a observação de pichações nas pedras das cachoeiras (Figura 7B) e a presença de uma construção (inacabada) na margem oposta do curso d'água. 


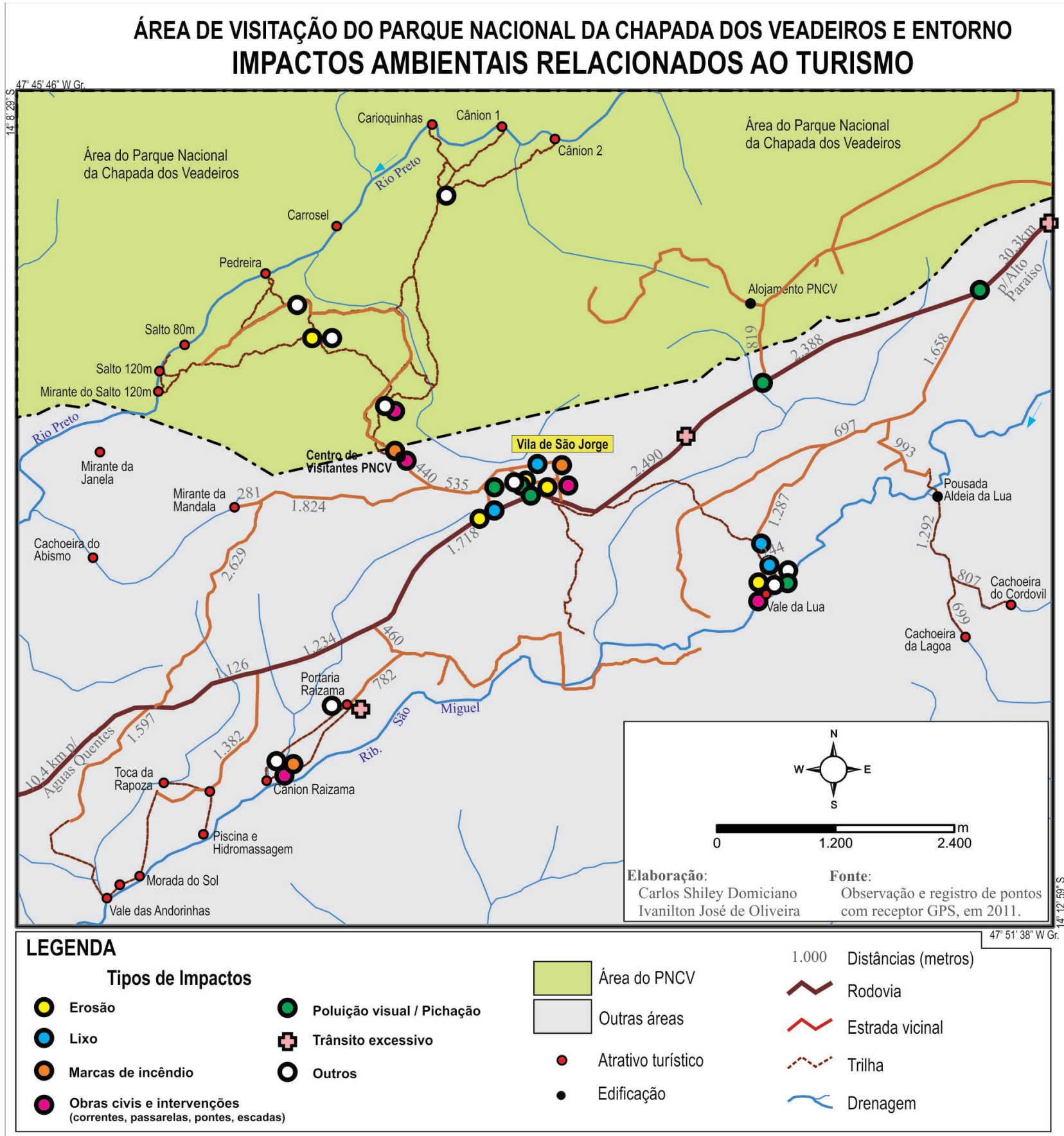

Figura 5 - Mapa dos impactos ambientais no PNCV, no Distrito de São Jorge e imediações (2011) 


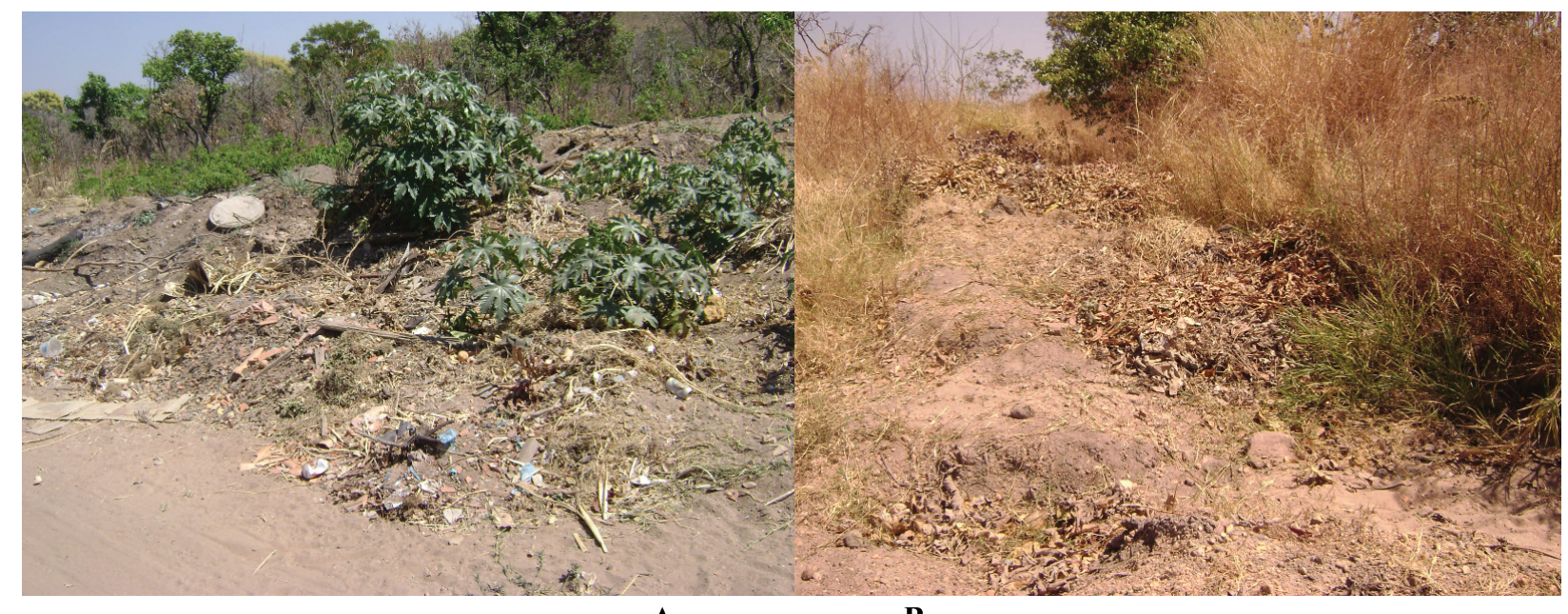

$\mathbf{A}$

B

Figura 6 - Deposição de lixo e entulho em locais inapropriados (set./2011).

Fonte: Os autores.

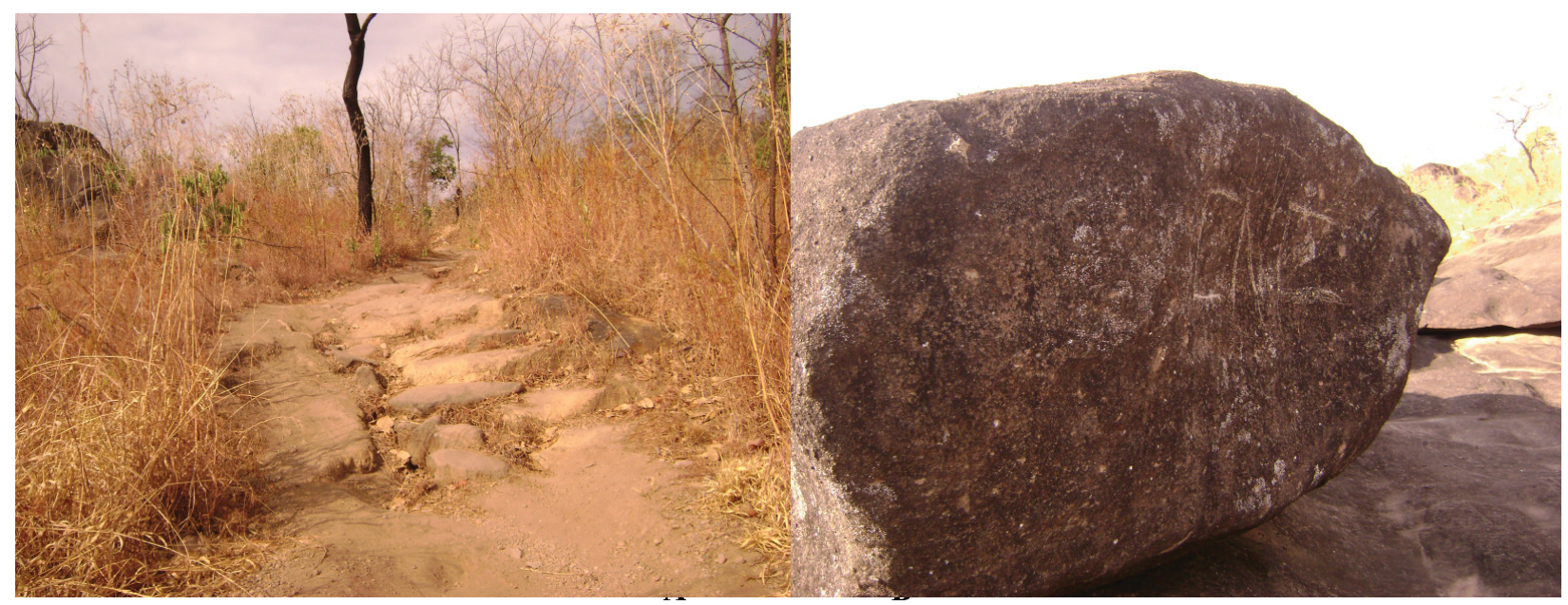

Figura 7 - Degradação de trilha e pichação de pedra em um atrativo turístico (set./2011).

Fonte: Os autores.

O PNCV, mesmo sendo uma UC, apresenta alguns impactos decorrentes da atividade turística que aí se desenvolve, nas trilhas que levam aos Saltos e Corredeiras do Rio Preto e aos Canyons e Cachoeira das Cariocas. Os percursos devem ser realizados estritamente acompanhados por guias, que fazem todo um trabalho de conscientização sobre a questão da preservação dos locais visitados.

Quanto aos impactos observados, destacam-se alguma degradação de trilha pelo uso constante pelos turistas; marcas de erosão nas partes mais íngremes, notando-se, em alguns locais, a contenção com pedras, o que denota um serviço de manutenção dessas trilhas. Pode-se observar também a presença de duas trilhas interditadas, uma em função de manejo ditado pelo Plano de Manejo do PNCV e outra, do Canyon I, em virtude de ser local de reprodução do pato mergulhão, segundo informações do guia condutor. De acordo com o MMA/ICMBio (2011), em situações como as descritas anteriormente, recomendam-se medidas para redução do uso de área onde possa haver maiores impactos, diminuindo-se o número de visitantes, desestimulando ou até proibindo o seu uso. Também foi possível notar, não só no Parque, mas nas imediações do Distrito de São Jorge, vestígios de queimada nos troncos das árvores, provenientes do incêndio ocorrido em 2010, que atingiu toda a região, segundo relatos de moradores locais e administradores do Parque e do Distrito. 
Em se tratando de impactos ambientais, não se pode deixar de ressaltar a existência, no PNCV, no Morro do Garimpão, dos sinais da antiga atividade predominante na região, as catas deixadas pelos garimpeiros; atualmente, transformadas em atração turística (Figura 8).

Apesar disto, ainda é lembrada a época do apogeu dos garimpos, mesmo dentro do Parque. A trilha para os Saltos do Rio Preto (tradicionalmente conhecidos como saltos do Garimpão), passa por trechos do antigo garimpo, onde até hoje se encontram resquícios das atividades extrativas minerais do início do século XX, proporcionando uma rica abordagem histórico-cultural, que agrega grande valor ao desenvolvimento de práticas turísticas e educativas (MMA/ICMBIO, 2009, p.23).

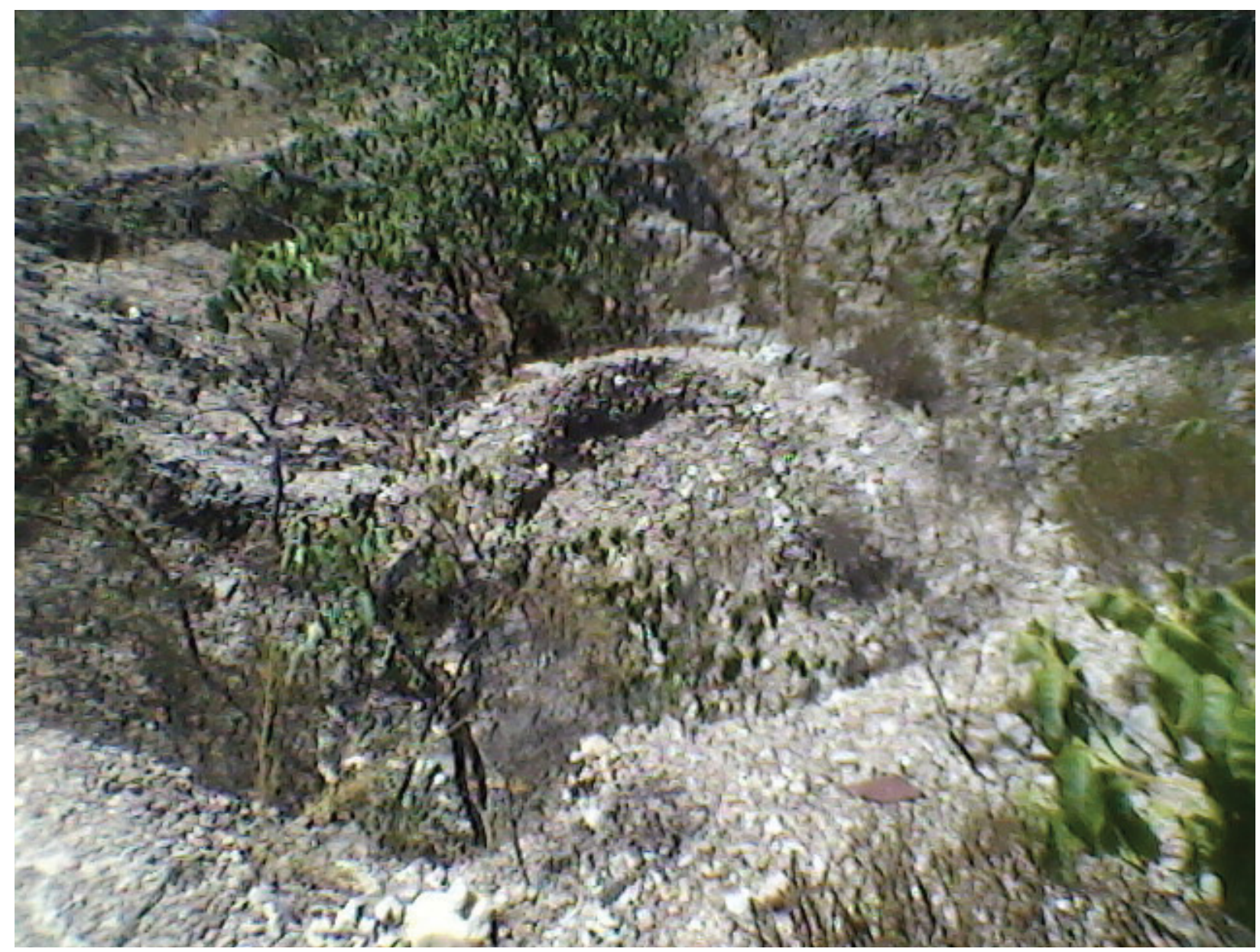

Figura 8 - Foto das catas do garimpo no PNCV (set./2011).

Fonte: Os autores.

Dos impactos ambientais observados em toda a região do PNCV, do Distrito e seu entorno, constatou-se que alguns deles são recorrentes em quase todos os locais, com uma maior abrangência espacial, com destaque para a ocorrência de erosão, de poluição visual decorrente de placas e pichações e a deposição de lixo em locais inapropriados. Tal observação pode ser corroborada com o que afirmam as orientações do MMA/ICMBio (2011, p.13): "os impactos gerados pela visitação pública podem ser ocasionados por inúmeras variáveis e podem ser descontínuos temporalmente ou espacialmente". Uma indicação de que os impactos podem ou não ocorrer em determinadas épocas - neste caso coincidindo com as temporadas do turismo; e em certos espaços - podendo ocorrer no interior do Parque, mas não fora dele, ou vice-versa.

Outra constatação acerca dos impactos reside na relação direta da dispersão espacial dos atrativos turísticos com a dispersão da ocorrência daqueles. Se os atrativos estão concentrados numa 
área menor, os impactos tendem a se avolumar e tornarem-se mais evidentes, como no caso dos atrativos nas propriedades particulares; ao passo que, com uma maior dispersão desses atrativos, há uma tendência dos impactos serem menos percebidos, como no caso das trilhas do PNCV, que são mais longas, diluindo a capacidade de percepção de quem os vê.

\section{OS IMPACTOS CONHECIDOS}

Os impactos conhecidos foram perscrutados a partir de uma pesquisa exploratória, por intermédio de entrevistas com moradores locais, administradores municipais da localidade e do PNCV, administradores dos empreendimentos particulares e turistas, com a finalidade de complementar e elucidar a pesquisa realizada em campo, somando-se ao intuito de captar como as pessoas percebem os impactos que são causados em função de suas "práticas sociais" e de suas relações com a "dinâmica física do ambiente" (ZACHARIAS et al., 2009). Corrobora, assim, com o que afirmaram Brandão e Barreto (2009, p. 368), de que "esses impactos ocorrem porque a Vila atrai turistas que possuem culturas variadas e, ao explorar os atrativos turísticos antes descritos, introduzem mudanças no cotidiano dos moradores antigos, pressionam o meio natural e a infra-estrutura social existente".

Para os turistas, os impactos mais destacados foram as "precárias condições da estrada" da GO-239, com seus "buracos e o pó", que dificultam o acesso ao Distrito/PNCV e seu entorno, com seus atrativos; o acúmulo de lixo em locais inapropriados, nas margens da estrada e no Distrito; os vestígios de fogo nos troncos das árvores, tanto no PNCV quanto nas suas imediações, marcas de um incêndio ocorrido no ano anterior; a estrutura física deficiente do Distrito de São Jorge com "instalações urbanas inadequadas". Algumas menções foram feitas pontualmente, em referência aos atrativos das propriedades particulares, a exemplo do excesso de pessoas nos locais, levando ao "comprometimento da capacidade de carga"; "as trilhas mal manejadas" e a "pichação das rochas", colocando em risco a integridade do patrimônio natural.

Concernente aos moradores, a sua percepção acerca dos impactos foca-se primeiramente na questão dos problemas com a estrada, fato que dificulta o acesso a Alto Paraíso, não somente pela poeira, na época seca, mas também a lama do período chuvoso. Foi mencionado o problema da erosão das ruas (Figura 9), cujo cascalho é carreado para um ribeirão (de nome Preguiça, segundo um morador) que passa nas proximidades do Distrito, provocando o "entupimento do rio".

Para um morador e guia, os impactos maiores residem na "degradação das trilhas" no interior do PNCV e o acúmulo de lixo nos atrativos das propriedades particulares no seu entorno, ao que ressalta: "no Parque, a importância do guia na consciência da preservação; fora do Parque, a falta do guia deixa a responsabilidade para o visitante, nem todos têm a consciência". Nesse relato, percebe-se a contribuição do guia no processo de preservação ambiental, bem como se pode subentender uma defesa da manutenção do seu trabalho.

De acordo com o agente da Administração Municipal Local do Distrito de São Jorge, os impactos ambientais provenientes da atividade turística são vários, dentre eles destacando-se o acúmulo de lixo, não só na sede do Distrito, como no trecho da estrada GO-239, que o margeia. Para o agente, esse problema se agrava mais na época de alta temporada (julho) e feriados prolongados, quando o número de turistas supera em muito o número de habitantes do Distrito. Outro agravante, segundo relatado, é a falta de conscientização das pessoas quanto ao destino do lixo, conferindo também certa responsabilidade aos proprietários de veículos de aluguel (caminhões) que fazem a captação de entulho/cisco para depositar em locais inapropriados. Ainda conforme o agente, já existe um serviço de coleta seletiva de lixo da Prefeitura Municipal de Alto Paraíso que está em funcionamento no Distrito, existindo um local apropriado para a separação do material. 


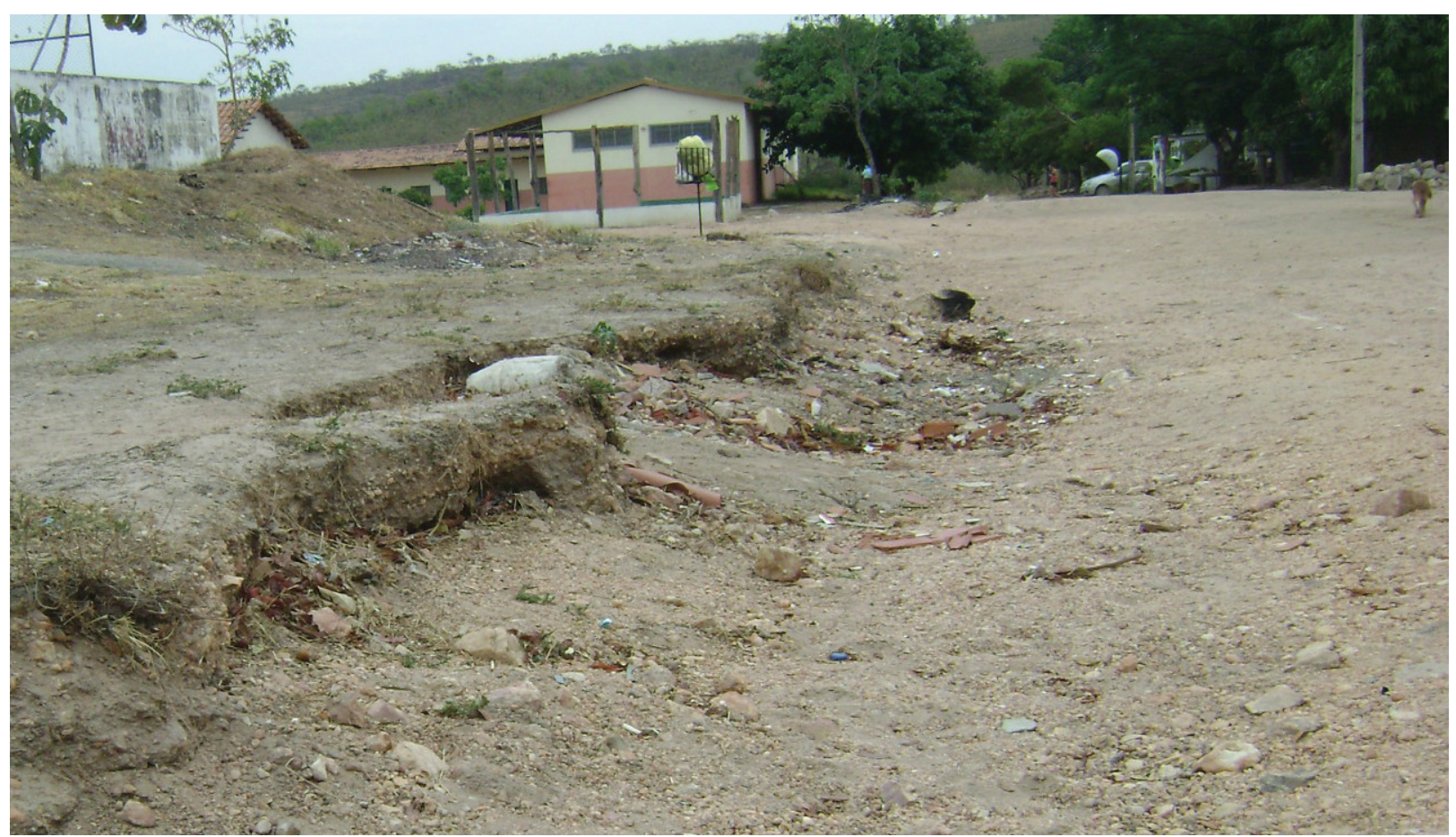

Figura 9 - Rua com erosão no Distrito de São Jorge (set./2011). Fonte: Os autores

Tal assunto é de tamanha relevância para o Distrito que, no período da realização da pesquisa, o ICMBio havia notificado a Prefeitura Municipal em função dessas deposições irregulares de lixo nas imediações do Distrito e do PNCV. Outros impactos que foram frisados pelo agente da Administração Local relacionam-se à poluição visual na "vila", vinculada às placas dos anúncios de pousadas, estabelecimentos comerciais e outros (Figura 10), sobrecarregando a paisagem do lugar, e a poluição sonora, advinda dos veículos e aparelhos de sons automotivos, por ocasião dos períodos de maior afluxo de turistas, tirando a tranquilidade do povoado.

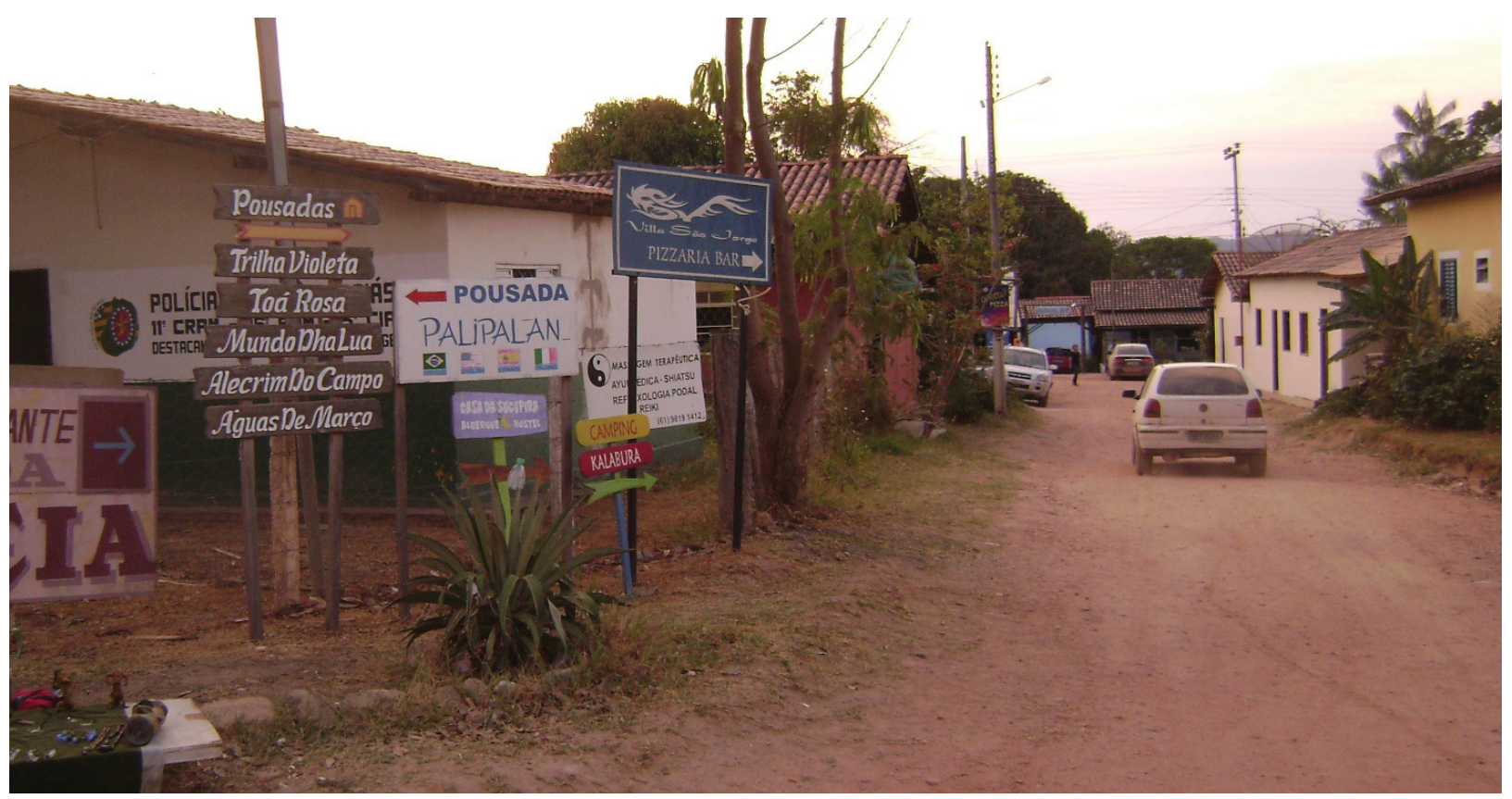

Figura 10: Poluição visual causada por placas na Vila de São Jorge (set./2011). Fonte: Os autores. 
O agente atribui esses problemas à inexistência, no distrito e seu entorno, de um dimensionamento da sua capacidade de carga turística, caso que pode ser convalidado pelo que expõe Cerro (1993), citado por Brandão e Barreto (2009, p. 358), sobre a aplicação dessa metodologia (capacidade de carga). "A extrapolação de tais limites faz aumentar os riscos de saturação do equipamento turístico, a degradação do meio ambiente e a redução da qualidade da experiência turística" (grifo nosso).

Por parte do PNCV, de acordo com um agente da administração, os impactos ambientais relacionados ao turismo que mais preocupam estão vinculados ao uso e ocupação do solo, em que "a especulação imobiliária" conduz a uma "supervalorização das terras" do local, "expulsando os nativos" e promovendo a "fragmentação dos ecossistemas", para a implantação de empreendimentos turísticos no espaço do Distrito e seu entorno. Esse fato ficou evidenciado pela observação das diversas obras de infraestrutura para aparelhamento dos atrativos turísticos da região, as denominadas "intervenções no espaço físico" (DIAS, 2003). Também foi destacado o volume de lixo gerado no Distrito nos feriados prolongados, um impacto que é recorrente em todos os relatos de entrevistados e observações realizadas. Segundo o mesmo agente, em relação ao Plano de Manejo do PNCV, as estratégias adotadas para evitar e/ou minimizar os efeitos dos impactos ambientais nas suas áreas de visitação e entorno são "aumento da fiscalização e cumprimento da legislação ambiental, com tolerância-zero, e educação ambiental nas escolas da região". Percebe-se assim, uma dupla ação em relação à questão ambiental por parte da instituição: controle e punição a quem infringe a lei e mudança de comportamento das futuras gerações.

Quanto à extensão dos impactos na localidade, o agente informou que, conforme a percepção da administração do PNCV, eles podem ser qualificados numa gradação que varia de pouco intenso, no seu grau mínimo, a intenso, no seu grau máximo, com referências intermediárias, sendo que as ocorrências avaliadas situam-se da parte mediana para cima dessa escala gradativa (Quadro 1). Os impactos, tais como queimadas, presença de plantas invasoras/animais domésticos e caça, foram avaliados como de grau intenso; desmatamento, assoreamento de cursos de água, pontos de deposição de lixo e atropelamento de animais silvestres foram avaliados entre intenso e medianamente intenso; e itens como erosão, coleta de plantas, coleta de materiais inertes (pedras, cristais etc.) e garimpo, foram avaliados como medianamente intenso.

Quadro 1 - Avaliação dos impactos sobre o PNCV e entorno.

\begin{tabular}{|c|c|c|c|}
\hline \multicolumn{4}{|c|}{ TIPOS DE IMPACTOS E NÍVEL DE AVALIAÇÃO } \\
\hline $\begin{array}{l}\text { Pouco Intenso } \\
\text { (PI) }\end{array}$ & Medianamente Intenso (MI) & Intermediário (MI/I) & $\begin{array}{l}\text { Intenso } \\
\text { (I) }\end{array}$ \\
\hline- & $\begin{array}{ll}\text { - } & \text { Erosão } \\
\text { - } & \text { Coleta de plantas } \\
\text { - } & \text { Coleta de materiais } \\
\text { inertes } \\
\text { - } & \text { Garimpos }\end{array}$ & $\begin{array}{ll}\text { - } & \text { Desmatamento } \\
\text { - } & \text { Assoreamento de cursos de } \\
\text { água } \\
\text { - } & \text { Pontos de deposição de lixo } \\
\text { - } & \begin{array}{l}\text { Atropelamento de animais } \\
\text { silvestres }\end{array}\end{array}$ & $\begin{array}{l}\text { - Queimadas } \\
\text { - Presença de plantas invasoras e de animais } \\
\text { domésticos } \\
\text { - Caça }\end{array}$ \\
\hline
\end{tabular}

Fonte: entrevista concedida pela Administração do PNCV em 2011. Organização dos autores.

Desses impactos expostos, alguns deles podem nem apresentar vinculação direta com a atividade turística, como as queimadas, por exemplo, que têm origem na atividade agropecuária. Todavia, a maior parte deles surge pelo desenrolar de atividades diretamente oriundas do setor turístico, 
como é o caso do acúmulo de lixo em determinado local, ou se originam para que o turismo possa acontecer, citando como exemplo a erosão da estrada, em função da manutenção da infraestrutura de transporte, que permite o ir e vir das pessoas e, por conseguinte, também o acesso a um certo atrativo turístico.

Os impactos decorrentes da atividade turística ficam, de certa forma, marcados no espaço onde o turismo acontece, ainda mais em se tratando de uma modalidade que tem por mote principal o ambiente, como é o caso do ecoturismo que se desencadeia no PNCV, no Distrito de São Jorge e nas suas imediações. São as impressões que ficam e que deixam transparecer o relacionamento das atuais "práticas sociais" com o seu meio.

\section{CONSIDERAÇÕES FINAIS}

A realização deste trabalho permitiu não só a percepção e a visualização dos impactos ambientais (ou socioambientais) no espaço do PNCV, no Distrito de São Jorge e seu entorno, como foi possível identificar, por meio das marcas observadas (impactos percebidos) e também daquelas captadas pelos turistas, moradores e administradores institucionais (impactos conhecidos), as práticas sociais pretéritas e as que ainda ocorrem no lugar, modificando a sua paisagem, desde a época da garimpagem, perpassando pelas atividades de subsistência ligada à agricultura e extrativismo, até os dias atuais, com o turismo, mais especificamente o ecoturismo.

Neste momento, a atividade turística torna-se a mais impactante, em especial nos locais de maior afluxo de pessoas, como a sede do Distrito de São Jorge, para onde todos se dirigem na busca dos atrativos da região, e também nas localidades em que não há um controle de visitação, com a exigência do acompanhamento de um guia de turismo, como nas propriedades particulares. E até no PNCV, mesmo sendo uma UC, em que se exige a visita acompanhada por guias de turismo, notou-se a incidência de impactos decorrentes da atividade. Pode-se perceber pelas ações dos turistas que, em sua maioria, eles ainda não têm uma preocupação com a questão ambiental, pois ainda aparentam possuir um enfoque mais voltado para a atividade do lazer, como a contemplação da paisagem, do "belo", sem se atinar para os impactos gerados.

Alguns impactos apresentam uma maior abrangência espacial e aparecem em todos os locais, nos quais a atividade turística se desenvolve, entre eles a ocorrência de erosão na estrada e nas ruas do Distrito de São Jorge, o acúmulo de lixo em locais indevidos, o registro de pichações em placas de sinalização e monumentos naturais, além do próprio acúmulo de placas, causando a poluição visual desses locais. Convém ressaltar que algumas dessas ocorrências, como é o caso do lixo, derivam também da participação dos moradores locais. Tais ações refletem, de certa maneira, uma forma de conduta das pessoas, ligada à falta de uma educação ambiental, como assegura o Plano de Manejo do PNCV, quando trata acerca da origem dos impactos em um ambiente: "qualquer ação humana tem algum nível de impacto que não depende somente do número de pessoas em um determinado lugar, mas especialmente do seu comportamento" (MMA/ICMBio, 2011, p.13).

Outrossim, constatou-se que muitos dos impactos registrados, tanto percebidos quanto conhecidos, são coincidentes, com a indicação de que constituem marcas representativas na paisagem do local, seja para aqueles que por aí passam esporadicamente - os turistas - ou para os que aí moram, trabalham, pesquisam, em constante interação com esse ambiente. Dessa forma, todos contribuem para a modificação do local, gerando algum tipo de impacto. Pois estes são marcos da própria ação humana na paisagem, que podem ser analisados e compreendidos, conquanto a paisagem seja, no entender de Martinelli e Pedrotti (2001, p, 41), “um processo de transformação inscrito na história [...] deixando de ser apenas o que se vê’." 
É de se esperar que este trabalho traga algum contributo para o despertar de uma consciência para uma educação ambiental daqueles que habitam, trabalham ou transitam pela região do PNCV; para o subsídio de políticas públicas voltadas para as áreas ambiental e de turismo. E, certamente, não se encerra aqui essa temática, suscitando novas empreitadas sobre o assunto.

\section{REFERÊNCIA BIBLIOGRÁFICA}

ALONSO, Juan Javier García-Abad. Cartografía Ambiental: desarrollo y propuesta de sistematización. Observatorio Medioambiental, Madrid, v. 5, 2002. p. 47-78.

ARCHELA, Rosely S.; ROSOLÉM, Nathália P. Legenda geral do mapa ambiental de Londrina: ensaio metodológico de cartografia. Confins, São Paulo, n.6, 2009. Disponível em: <http://confins.revues.org/5900>. Acesso em: ago. 2011.

BENI, Mário C. Análise estrutural do turismo. 7. ed. São Paulo: Editora SENAC, 2002.

BRANDÃO, Paulo A.C.A.; BARRETO, Renata V. Impactos Ambientais do Ecoturismo na Vila de São Jorge, entrada do Parque Nacional do Parque dos Veadeiros. In: STEINBERGER, Marília. Territórios Turísticos no Brasil Central. Brasília: LGE Editora, 2009.

DIAS, Reinaldo. Turismo sustentável e meio ambiente. São Paulo: Atlas, 2003.

FONTELES, José O. Turismo e impactos socioambientais. São Paulo: Aleph, 2004.

JOURNAUX, André. Cartographie intégrée de l'environnement: un outil pour la recherche et pour l'aménagement. Notes Tecniques du MAB, 16. s.l., UNESCO, 1985.

LEMOS, Leandro. O valor turístico na economia da sustentabilidade. São Paulo: Aleph, 2005.

MARTINELLI, Marcello; PEDROTTI, Franco. A cartografia das unidades de paisagem: questões metodológicas. Revista do Departamento de Geografia USP, São Paulo, n.14, p.39-46, 2001.

MENDONÇA FILHO, Dálio R. O estudo do ecoturismo praticado na Chapada dos Veadeiros, no Estado de Goiás, Brasil. Uma visão ambiental estratégica. Dissertação (Mestrado em Política e Gestão Ambiental) - Centro de Desenvolvimento Sustentável, UnB, 2007. Disponível em: <http://www.unbcds. pro.br/pub>. Acesso em: ago. 2011.

MINISTÉRIO DO MEIO AMBIENTE - MMA. Resolução 001/86 do CONAMA. Disponível em: <http:// www.mma.gov.br/port/conama/legiano $>$. Acesso em: ago. 2011.

MINISTÉRIO DO MEIO AMBIENTE - MMA/INSTITUTO CHICO MENDES DE CONSERVAÇÃO DA BIODIVERSIDADE - ICMBio. Plano de Manejo do Parque Nacional da Chapada dos Veadeiros - Resumo Executivo. Brasília, 2009. Disponível em: <www.icmbio.gov.br/parna_veadeiros >. Acesso em: out. 2011.

MINISTÉRIO DO MEIO AMBIENTE - MMA/INSTITUTO CHICO MENDES DE CONSERVAÇÃO DA BIODIVERSIDADE - ICMBio. Roteiro Metodológico Para Manejo de Impactos de Visitação com Enfoque na Experiência do Visitante e na Proteção dos Recursos Naturais e Culturais. Brasília, 2011. Disponível em: <www.icmbio.gov.br/portal/images/stories/comunicacao/roteiro_impacto.pdf $>$. Acesso em: nov. 2011.

OLIVEIRA, Ivanilton José de. A linguagem dos mapas: utilizando a cartografia para comunicar. Revista Temporis(ação), Goiás, v. 1, n. 8, p.37-62, 2005.

OLIVEIRA, Ivanilton José de. Cartografia turística para a fruição do patrimônio natural da Chapada dos Veadeiros. Tese (Doutorado em Geografia) - Departamento de Geografia, Universidade de São Paulo, 2007. $200 \mathrm{fl}$.

PREFEITURA MUNICIPAL DE ALTO PARAÍSO DE GOIÁS. Plano Diretor Ambiental/Urbano. Alto Paraíso de Goiás, 1998. Disponível em: <www.alto.paraiso.nom.br/aparaiso/solos.htm> Acesso em: out. 2011. 
RECH, Claudia M. C. B.; OLIVEIRA, Kênya N.; LOCH, Ruth E. M. Orientações para elaborar um mapa temático turístico. Revista Coordenadas - Turismo e Gerenciamento. Itajaí, v.2, n.2, mar./jul./nov. 2007. Disponível em: <http://www2.ifes.com.br/webifes/revista/edi\%E7\%F5es.htm>. Acesso em: ago. 2011.

ROCKTAESCHEL, Benita M.M.M. Terceirização em áreas protegidas: Estímulo ao ecoturismo no Brasil. São Paulo: Editora Senac, 2006.

ROZO, Edna. El turismo sustentable como promotor del desarrollo de las comunidades locales. In: KRUMHOLZ, Daniel M. Turismo e desarollo sostenible. Bogotá: Universidad Externado de Colombia. 2002. p. 123-140.

SILVA, Clarinda A. Paisagem - Campo de visibilidade e de significação sócio-cultural: Parque Nacional da Chapada dos Veadeiros e Vila de São Jorge. Dissertação (Mestrado em Geografia), Universidade Federal de Goiás. Goiânia, 2003.

SILVA, Juliana M.O.; DA SILVA, Edson V. Cartografia aplicada ao planejamento ambiental em Unidade de Conservação no município de Beberibe - Ceará. UFV, 2009. Disponível em: <http://www.geo.ufv. br>. Acesso em: ago. 2011.

SILVA, Elisangela A.M.; NUNES, Luzia. Efeitos socioeconômicos da infra-estrutura de transportes nas localidades turísticas - Pavimentação da estrada GO-239 na Vila de São Jorge/GO. In: X ENCONTRO DE GEÓGRAFOS DA AMÉRICA LATINA - 20 a 26 de março de 2005, USP - São Paulo, Anais... São Paulo, 2005. Disponível em: <http://observatoriogeograficoamericalatina.org.mx>. Acesso em: ago. 2011.

SOARES, Marcello. Impactos do turismo: os efeitos do ecoturismo em Unidades de Conservação. Revista Coordenadas - Turismo e Gerenciamento. Itajaí, v.2, n.2, mar./jul./nov., 2007. Disponível em: <http:// www2.ifes.com.br/webifes/revista/edi\%E7\%F5es.htm>. Acesso em: ago. 2011.

ZACHARIAS, Andréa A. et al. A cartografia de síntese no planejamento e gestão ambiental. XIII Simpósio Brasileiro de Geografia Física Aplicada. UFV, 2009. Disponível em: <http://www.geo.ufv.br/simposio/ simposio/trabalhos/comunicacao_coordenada/001.pdf. Acesso em agosto/2011>. Acesso em: ago. 2011.

Trabalho enviado em fevereiro de 2012 Trabalho aceito em março de 2012 